\title{
ОСОБЛИВОСТІ РЕГРЕСІЙНОЇ ЗАЛЕЖНОСТІ ОЗНАК У КОРІВ ГОЛШТИНСЬКОЇ ПОРОДИ РІЗНОЇ СЕЛЕКЦІЇ
}

\author{
Підпала Тетяна Василівна \\ доктор сільськогосподарських наук, просресор \\ Миколаївський національний аграрний університет \\ ORCID: 0000-0002-4072-7576; \\ E-mail: pidpala@mnau.edu.ua \\ Стріха Людмила Олександрівна \\ кандидат сільськогосподарських. наук, доцент \\ Миколаївський національний аграрний університет \\ ORCID: 0000-0002-9847-6036 \\ E-mail: strikha.luda@gmail.com \\ Шевчук Наталя Петрівна \\ асистент \\ Миколаївський національний аграрний університет \\ ORCID: 0000-0002-5845-2582 \\ E-mail: shev4uk.n@ukr.net \\ Зайцев Євген Миколайович \\ кандидат сільськогосподарських наук \\ АБМ Трейд, Україна \\ ORCID: 0000-0002-4165-4196 \\ E-mail: zaitsev_yevhen@ukr.net
}

У процесі дослідження використані загальноприйняті зоотехнічні методи (індивідуальний облік молочної продуктивності, відтворювальної здатності), лабораторні (визначення якісного складу молока), варіаційно-статистичний метод (регресійний аналіз). Матеріалом для дослідження були дані молочної продуктивності та відтворювальної здатності корів двох поколінь голштинської породи німецької ( $n=362)$ та української $(n=350)$ селекції. Порівняльним аналізом встановлено, що корови голштинської породи німецької селекції характеризувалися нижчими коефіцієнтами регресії ознак молочної продуктивності, за винятком вмісту білка в молоці, ніж тварини голштинської породи української селекції. Разом з тим, спостерігаємо у них від'ємну регресійну залежність за вмістом жиру в молоці $\left(b_{\text {дмм }}=-0,182\right)$, що можна пояснити змінами, які відбуваються у процесі пристосування імпортованої худоби до нових технологічних умов експлуатації. У корів голштинської породи української селекції встановлено прямолінійну регресійну залежність ознак молочної продуктивності: надій за 305 днів лактації (bдм $=0,274)$, кількість молочного жиру (bдм $=0,279)$ і кількість молочного білка (bдм $=0,258)$, кількість молочного жиру за лактацію ( $\left.b_{\text {дм }}=0,227\right)$ i за добу $\left(b_{\text {д/м }}=0,295\right)$. Встановлено, що корови голштинської породи німецької селекції, не зважаючи на існування в дещо інших природно-кліматичних і кормових умовах, зберігають не лише високий рівень продуктивних ознак, а й відтворювальну здатність. За результатами регресійного аналізу встановлено наявність прямолінійної залежності як між селекційними ознаками, так і за окремими ознаками у споріднених групах тварин (дочки-матері). Це, в свою чергу, дозволило уточнити результативність селекції при формуванні високопродуктивного стада голштинської породи, яке відбувається шляхом завезення маточного поголів'я і використання бугаїв-поліпшувачів. Порівняльним аналізом коефіиієнтів регресії продуктивних ознак голштинських корів української селекції виявлено, що більще уваги надається підвищенню молочності у тварин і за рахунок иього відбувається збільшення кількості молочного жиру та білка у дочок, що походять від матерів різного рівня продуктивності. За результатами регресійного аналізу встановили, що селекцію молочної худоби голштинської породи на підвищення білковомолочності слід продовжувати, оскільки селекція на жирномолочність значно менше сприятиме збільшенню вмісту білка в молоці.

Ключові слова: голштинська порода, продуктивні ознаки, рівень надою, регресія.

DOI: https://doi.org/10.32845/bsnau.Ivst.2021.2.18

Селекція спрямовано діє на господарськи корисні ознаки сільськогосподарських тварин, зокрема молочної худоби. Завдяки методам та прийомам розведення, відбору та підбору створюються тварини бажаного генотипу, яким властиві характеристики придатності до використання в сучасних технологічних умовах. 3 часом вимоги до бажаного типу змінюються за кількістю і складом ознак селекції, враховується досягнутий рівень їх розвитку, соціальноекономічна необхідність та біологічна можливість їхнього

поліпшення. Широкого використання набувають сучасні методи селекції для поліпшення місцевих та удосконалення новостворених порід великої рогатої худоби. Отже, в процесі селекції змінюється рівень прояву господарськи корисних ознак у тварин, а тому актуальним є дослідження залежності результативних ознак селекції у молочної худоби.

В процесі селекції великої рогатої худоби виникає потреба визначення, наскільки в середньому змінюється величина однієї ознаки при зміні на одиницю міри іншої 
ознаки і для цього використовують регресійний аналіз. Порівнюючи величини коефіцієнтів регресії визначають збільшення (або зменшення) середнього значення однієї ознаки відносно іншої [3].

у результаті оцінки адаптаційних особливостей голштинів німецької селекції було встановлено за визначеним коефіцієнтом регресії, що надій первісток збільшується на 275 кг молока із підвищенням загальної оцінки за екстер'єрний тип на один бал [2]. Оцінюючи вплив матерів батьків на надій корів української червоної молочної породи шляхом виведення рівняння трифакторної регресійної залежності, встановили, що зі збільшенням надою у матерів на 1 кг молока надій у дочок підвищився на 60 кг [5].

Між варіюючими ознаками можуть мати місце не лише прямолінійні, а й криволінійні зв'язки [4]. Прикладом може бути шатроподібна форма лактаційної кривої, збільшення молочної продуктивності при підвищенні живої маси, але до певної граничної величини [7].

У тварин частіше проявляється криволінійна залежність між ознаками, тобто зі збільшенням однієї ознаки відбувається підвищення й іншої ознаки, яка з нею взаємозалежна, але потім спостерігається її зменшення. Це певним чином відображає ті біологічні закономірності, які виникають під впливом селекції в популяціях великої рогатої худоби. Не виключенням $€$ голштинська порода, яка істотно прискорює темпи підвищення молочної продуктивності корів, проте відрізняється деяким погіршенням відтворювальної здатності $[15,5]$, що стало наслідком інтенсивної селекції за продуктивними ознаками.

Встановлено кореляційну залежність та частку впливу на молочну продуктивність корів живої маси в різні періоди росту й розвитку телиць [14], визначено співвідносну мінливість між промірами, що формують індекси будови тіла та надоєм корів за лактацію [16].

Дослідженнями селекційних змін в популяції голштинської породи за чотири суміжних генерації встановлено за показниками асиметрії та ексцесу, що має місце природній дизруптивний відбір в популяції, який супроводжується зниженням продуктивності тварин за менш сприятливих умов [13]. У результаті оцінки селекційної ситуації в стадах встановлено, що поліпшення господарськи корисних ознак у молочної худоби племінних стад Тернопільської області доцільно проводити у напрямку підвищення жирномолочності, живої маси, конституційної міцності тварин [17].

Наразі значна увага приділяється вирішенню проблеми довголіття молочної худоби, підвищення продуктивного довголіття $[8,9,10,11]$, що розширює необхідність застосування кореляційного та регресійного аналізу для встановлення зв'язків між ознаками і, особливо тими, що характеризують продуктивні, відтворювальні, технологічні та адаптаційні властивості тварин.

Meта дослідження. Оцінити залежність змін господарськи корисних ознак у корів голштинської породи, що належать до популяцій німецької та української селекції. Зазначена мета виконувалася через такі завдання: визначити коефіцієнт прямолінійної регресії у корів голштинської породи різної селекції; встановити за коефіцієнтами регресії селекційні зміни у суміжних поколіннях; довести залежність продуктивності корів-дочок від рівня надою корів-матерів.

Матеріали та методи досліджень. В умовах племінного заводу СТОВ «Промінь» Арбузинського району
Миколаївської області виконувалися дослідження з встановлення регресійної залежності господарськи корисних ознак у корів голштинської породи німецької та української селекції. Запроваджена технологія виробництва забезпечує комфортність експлуатації молочної худоби і реалізацію генетичного потенціалу голштинської породи за умов безприв'язного боксового утримання, однотипної годівлі тварин повнораціонними моносумішами, доїнні корів на установці типу «Карусель», яка розрахована на обслуговування 80 корів. Середній надій на одну корову в 2019 році становив 11906 кг молока, а в 2020 році - 12016 кг молока. Основою одержання високої молочної продуктивності корів є створення таких умов годівлі, при яких використання обмінної енергії та інших поживних речовин $є$ максимальним. Для управління інформацією на молочному комплексі СТОВ «Промінь» використовується сукупність програмних інструментів, які й забезпечують рух інформаційного потоку відповідно до технологічних процесів з виробництва продукції молочного скотарства [18].

Матеріалом для дослідження були дані молочної продуктивності та відтворювальної здатності корів двох поколінь голштинської породи німецької $(n=362)$ та української $(n=350)$ селекції. Корів-матерів і корів-дочок також розподілили на групи за рівнем надою згідно відхилення $\bar{X} \pm 0,67$ б. Розвиток ознак оцінювали за даними надою, вмісту жиру і білка в молоці, кількістю молочного жиру і білка, кількістю молочного жиру за добу [19, 7] як за 305 днів, так і за всі дні першої лактації, за показниками відтворювальної здатності. Коефіцієнти лінійної регресії визначали, використовуючи регресійний аналіз $[1,7]$.

Результати досліджень. Для виявлення особливостей формування високої продуктивності в молочної худоби у відкритій популяції з використанням методів прямої та опосередкованої інтродукції генетичного матеріалу, визначили коефріцієнти регресії у піддослідних тварин голштинської породи німецької та української селекції (табл. 1).

Порівняльним аналізом встановлено, що корови голштинської породи німецької селекції характеризуються нижчими коесіцієнтами регресії ознак молочної продуктивності, за винятком вмісту білка в молоці, ніж тварини голштинської породи української селекції. Разом з тим, спостерігаємо у них від'ємну регресійну залежність за вмістом жиру в молоці (bд/м = -0,182), що можна пояснити змінами, які відбуваються у процесі пристосування імпортованої худоби до нових технологічних умов експлуатації.

Для імпортованих корів голштинської породи канадської селекції та їх дочок рівняння регресії сервіс-періоду на надій свідчило, що з його підвищенням на кожні 1000 кг тривалість сервіс-періоду подовжується на 7 днів, а збільшення віку першого отелення на один місяць сприяло зростанню надою на 75 кг молока [6].

У корів голштинської породи української селекції встановлено прямолінійну регресійну залежність ознак молочної продуктивності: надій за 305 днів лактації (bд/м = 0,274), кількість молочного жиру (bд/м $=0,279)$ і кількість молочного білка (b/м $=0,258)$, кількість молочного жиру за лактацію ( $\left.\mathrm{b}_{д / \mathrm{M}}=0,227\right)$ і за добу $\left(\mathrm{b}_{д / \mathrm{M}}=0,295\right)$. Поряд із зазначеним, мають місце і від'ємні регресійні залежності, зокрема це ознаки, що характеризують відтворювальну та адаптаційну здатність тварин, зокрема: тривалість сервіс-

Вісник Сумського національного аграрного університету 
періоду ( $\mathrm{b}_{\text {д/м }}=-0,007$ і $\left.-0,061\right)$, коефіцієнт відтворювальної здатності ( $\mathrm{b}_{д / м}=-0,040$ і -0,086), а тривалість міжотельного

періоду ( $\left.\mathrm{b}_{д / \mathrm{M}}=-0,076\right)$ та індекс адаптації ( $\left.\mathrm{b}_{д / \mathrm{M}}=-0,094\right)$.

Коефіцієнт регресії господарськи корисних ознак корів-первісток голштинської породи різної селекції

\begin{tabular}{|c|c|c|c|c|}
\hline \multirow{3}{*}{ Ознака } & \multicolumn{4}{|c|}{ Голштинська порода } \\
\hline & \multicolumn{2}{|c|}{ німецької селекції } & \multicolumn{2}{|c|}{ української селекції } \\
\hline & $b_{\text {дाM }}$ & $p$ & $b_{\text {ДIM }}$ & $p$ \\
\hline Тривалість лактації & 0,011 & 0,894 & $-0,067$ & 0,446 \\
\hline Надій за всю лактацію & 0,001 & 0,994 & 0,099 & 0,063 \\
\hline Надій за 305 днів лактації & 0,159 & 0,104 & 0,274 & 0,002 \\
\hline Вміст жиру в молоці & $-0,182$ & 0,033 & 0,001 & 0,998 \\
\hline Кількість молочного жиру & 0,079 & 0,400 & 0,279 & 0,005 \\
\hline Вміст білка в молоці & 0,134 & 0,081 & 0,016 & 0,912 \\
\hline Кількість молочного білка & 0,182 & 0,069 & 0,258 & 0,060 \\
\hline Кількість молочного жиру за всю лактацію & $-0,021$ & 0,799 & 0,227 & 0,039 \\
\hline Кількість молочного жиру за добу & 0,067 & 0,429 & 0,295 & 0,002 \\
\hline Тривалість сервіс-періоду & $-0,007$ & 0,937 & $-0,061$ & 0,490 \\
\hline Тривалість сухостійного періоду & $-0,023$ & 0,608 & 0,103 & 0,103 \\
\hline Тривалість МОП & 0,004 & 0,960 & $-0,076$ & 0,374 \\
\hline Коефріцієнт відтворювальної здатності & $-0,040$ & 0,722 & $-0,086$ & 0,243 \\
\hline Індекс адаптації & 0,017 & 0,851 & $-0,094$ & 0,128 \\
\hline
\end{tabular}

Отже, корови голштинської породи німецької селекції, не зважаючи на існування в дещо інших природнокліматичних і кормових умовах, зберігають не лише високий рівень продуктивних ознак, а й відтворювальну здатність.

За допомогою регресійного аналізу можна також визначити результативність селекції, що здійснювалася в процесі формування високопродуктивного стада з молочної худоби голштинської породи різної селекції. Тому регресію визначали не лише за фенотиповими показниками у спорід- нених груп тварин (дочки-матері), а й між ознаками у тварин двох суміжних поколінь.

У господарстві СТОВ «Промінь» селекційно-племінна робота 3 худобою голштинської породи цілеспрямовано проводиться на підвищення молочності та білковомолочності, оскільки це зумовлено сучасними вимогами молочного бізнесу. Зазначена особливість формування високопродуктивного стада знайшла своє обґрунтування даними регресійного аналізу (табл. 2).

Таблиця 2

Коефіцієнт регресії продуктивних ознак корів-первісток двох поколінь

\begin{tabular}{|c|c|c|c|c|}
\hline \multirow{3}{*}{ Співвідносні ознаки } & \multicolumn{4}{|c|}{ Голштинська порода } \\
\hline & \multicolumn{2}{|c|}{ німецької селекції } & \multicolumn{2}{|c|}{ української селекції } \\
\hline & $R_{x / y}$ & $R_{y / x}$ & $R_{x / y}$ & $R_{y / x}$ \\
\hline & \multicolumn{2}{|c|}{ Матері $(n=181)$} & \multicolumn{2}{|c|}{ Матері $(n=175)$} \\
\hline Надій - вміст жиру в молоці & 671,4 & 0,000 & 1085,0 & 0,000 \\
\hline Надій - кількість молочного жиру & 22,1 & 0,037 & 24,0 & 0,038 \\
\hline Надій - вміст білка в молоці & 3195,0 & 0,000 & 1200,1 & 0,000 \\
\hline Надій - кількість молочного білка & 28,5 & 0,030 & 30,8 & 0,030 \\
\hline \multirow[t]{2}{*}{ Вміст жиру - вміст білка в молоці } & 0,102 & 0,024 & 0,450 & 0,078 \\
\hline & \multicolumn{2}{|c|}{ Дочки $(\mathrm{n}=181)$} & \multicolumn{2}{|c|}{ Дочки $(\mathrm{n}=175)$} \\
\hline Надій - вміст жиру в молоці & 92,4 & 0,000 & 327,0 & 0,000 \\
\hline Надій - кількість молочного жиру & 23,2 & 0,040 & 20,5 & 0,040 \\
\hline Надій - вміст білка в молоці & 1623,8 & 0,000 & 865,9 & 0,000 \\
\hline Надій - кількість молочного білка & 29,7 & 0,030 & 28,5 & 0,030 \\
\hline Вміст жиру - вміст білка в молоці & 0,531 & 0,083 & 1,916 & 0,372 \\
\hline
\end{tabular}

Враховуючи важливість білковомолочності, проаналізували регресійну залежність між якісними ознаками. Так, із збільшенням вмісту білка в молоці на 1,0 \% жирномолочність в середньому підвищується на 0,102 \% у матерів і на $0,531 \%$ у дочок. I навпаки, зі збільшенням вмісту жиру в молоці на 1,0 \% білковомолочність в середньому підвищується на 0,024 \% у матерів і на 0,083 \% у дочок. Порівнюючи величини коефіцієнтів регресії $R_{x / y}$ і $R_{y / x}$ встановили, що підвищення відсоткового вмісту білка значно менше, ніж жиру, при зміні поєднаного з ним компонента на одиницю. За результатом наведеного регресійного аналізу можна зробити заключення, що селекцію молочної худоби голштинської породи на підвищення білковомолочності слід продовжувати, оскільки селекція на жирномолочність значно менше сприятиме збільшенню вмісту білка в молоці.
Аналогічна тенденція регресії проявляється й за деякими іншими ознаками молочної продуктивності. Порівнюючи величини коефріцієнтів регресії між надоєм і кількістю молочного жиру, надоєм і кількістю молочного білка, визначили їх збільшення у матерів і дочок залежно від того, яка ознака є основною при відборі та підборі тварин.

Загальновідомо, що перевагу в селекції молочної худоби надають високопродуктивним коровам. При цьому виявлення регресійної залежності ознак у дочок і матерів, в групах розподілених за рівнем надою матерів, характеризує зумовленість продуктивності в їх потомків.

На підставі визначених коефіцієнтів регресії у корів голштинської породи німецької селекції встановили, що величина зміни надою у дочок в групі «>9373» у меншій мірі залежить від материнської спадковості $R_{y / x}=0,004$ і $R_{x / y}=$ 
0,027, ніж у тварин груп «<8553» і «8554-9372», у яких величини коефіцієнтів вищі і становлять: $R_{y / x}=0,127 ; R_{x / y}=0,575$

і $R_{y / x}=0,018 ; R_{x / y}=0,680$ відповідно (табл. 3).

Коефіцієнт регресії продуктивних ознак дочок (x) та їх матерів (y), розподілених в групи за рівнем надою матерів (голштинська порода німецької селекції)

\begin{tabular}{|c|c|c|c|c|c|c|}
\hline \multirow{3}{*}{ Ознака } & \multicolumn{6}{|c|}{ Група за рівнем надою корів-матерів } \\
\hline & \multicolumn{2}{|c|}{$<8553$} & \multicolumn{2}{|c|}{$8554-9372$} & \multicolumn{2}{|c|}{$>9373$} \\
\hline & $R_{y / x}$ & $R_{x / y}$ & $R_{y / x}$ & $R_{x / y}$ & $R_{y / x}$ & $R_{x / y}$ \\
\hline Надій за 305 днів лактації & 0,127 & 0,575 & 0,018 & 0,680 & 0,004 & 0,027 \\
\hline Вміст жиру в молоці & 0,073 & 0,111 & 0,158 & 0,307 & 0,021 & 0,074 \\
\hline Кількість молочного жиру & 0,066 & 0,277 & 0,018 & 0,201 & 0,021 & 0,074 \\
\hline Вміст білка в молоці & 0,173 & 0,147 & 0,046 & 0,034 & 0,307 & 0,400 \\
\hline Кількість молочного білка & 0,145 & 0,580 & 0,021 & 0,481 & 0,058 & 0,336 \\
\hline
\end{tabular}

Дана тенденція зберігається і є характерною для голштинської породи німецької селекції Проте, за білковомолочністю виявлено іншу тенденцію, особливістю якої є вищі коесріцієнти регресії у тварин групи «>9373» порівняно з менш продуктивними - «<8553» і «8554-9372». Значення коефіцієнтів регресії вказують на те, що із підвищенням вмісту білка в молоці корів-матерів на 1,0 \% вміст білка в молоці їхніх дочок в середньому збільшиться на 0,400 \%. । навпаки, визначена регресія матерів за показниками дочок вказує на те, що для підвищення в середньому вмісту білка в молоці корів-дочок на 1,0 \% у їхніх матерів це збільшення в середньому повинно становити 0,307 \%.

Аналогічно визначена регресія й для корів голштинської породи української селекції. Встановлена прямолінійна регресійна залежність за досліджуваними ознаками у дочок та їх матерів. Коефіцієнти регресії між надоєм дочок і надо- єм їх матерів $\left(R_{x / y}\right)$ в усіх групах майже подібні: «<7129»$R_{x / y}=0,500 ; 《 7130-8898 »-R_{x / y}=0,451 \mathrm{i}$ «>8899»- $R_{x / y}=$ 0,381 (табл. 4).

За іншими продуктивними ознаками, також спостерігаємо прямолінійну регресійну залежність, але величини коефріцієнтів регресії дещо менші, за винятком кількості молочного жиру («<7129» - $R_{x / y}=0,801 \mathrm{i}$ «7130-8898» $-R_{x / y}$ $=0,577)$ і кількості молочного білка ( $<7129 »-R_{x / y}=0,686$; «7130-8898»- $\left.R_{x / y}=0,433 \mathrm{i} «>8899 »-R_{x / y}=0,386\right)$.

Отже, у результаті порівняльного регресійного аналізу продуктивних ознак голштинських корів української селекції виявлено, що більше уваги надається підвищенню молочності тварин і за рахунок цього відбувається збільшення кількості молочного жиру та білка у дочок, отриманих від матерів різного рівня продуктивності.

Коефіцієнт регресії продуктивних ознак дочок (х) та їх матерів (y), розподілених в групи за рівнем надою матерів (голштинська порода української селекції)

\begin{tabular}{|c|c|c|c|c|c|c|}
\hline \multirow{3}{*}{ Ознака } & \multicolumn{6}{|c|}{ Група за рівнем надою корів-матерів } \\
\hline & \multicolumn{2}{|c|}{$<7129$} & \multicolumn{2}{|c|}{$7130-8898$} & \multicolumn{2}{|c|}{$>8899$} \\
\hline & $R_{y / x}$ & $R_{x / y}$ & $R_{y / x}$ & $R_{x / y}$ & $R_{y / x}$ & $R_{x / y}$ \\
\hline Надій за 305 днів лактації & 0,058 & 0,500 & 0,070 & 0,451 & 0,059 & 0,381 \\
\hline Вміст жиру в молоці & 0,083 & 0,173 & 0,014 & 0,066 & 0,173 & 0,148 \\
\hline Кількість молочного жиру & 0,050 & 0,801 & 0,100 & 0,577 & 0,042 & 0,150 \\
\hline Вміст білка в молоці & 0,052 & 0,152 & 0,014 & 0,044 & 0,026 & 0,034 \\
\hline Кількість молочного білка & 0,077 & 0,686 & 0,059 & 0,433 & 0,051 & 0,386 \\
\hline
\end{tabular}

Висновки. За результатами досліджень встановлено, що корови голштинської породи німецької селекції, не зважаючи на існування в дещо інших природно-кліматичних кормових умовах, зберігають не лише високий рівень продуктивних ознак, а й відтворювальну здатність.

За результатами регресійного аналізу встановлено наявність прямолінійної залежності як між селекційними ознаками, так і за окремими ознаками у споріднених групах тварин (дочки-матері). Це, в свою чергу, дозволило уточнити результативність селекції при формуванні високопродуктивного стада голштинської породи, яке відбувається шляхом завезення маточного поголів'я і використання бугаїв- поліпшувачів.

Порівняльним регресійним аналізом продуктивних ознак голштинських корів української селекції виявлено, що більше уваги надається підвищенню молочності у тварин і за рахунок цього відбувається збільшення кількості молочного жиру та білка у дочок, що походять від матерів різного рівня продуктивності.

За результатами регресійного аналізу встановили, що селекцію молочної худоби голштинської породи на підвищення білковомолочності слід продовжувати, оскільки селекція на жирномолочність значно менше сприятиме збільшенню вмісту білка в молоці.

\section{Список використаної літератури:}

1. Аналіз біометричних даних у розведенні та селекції тварин / С. С. Крамаренко, С. І. Луговий, А. В. Лихач, О. С. Крамаренко. Миколаїв, МНАУ. 2019. 211 с.

2. Бащенко М. І., Хмельничий Л. М. Адаптаційні особливості голштинів німецької селекції // Розведення і генетика тварин : міжвід. тематич. наук. зб. : матеріали наук.-вироб. конференції «Нове в селекції, генетиці та біотехнології тварин». К. : Науковий світ ТМ, 2002. Вип. 36. С. 28-29.

3. Гиль М. І. Компоненти фенотипової мінливості селекційних ознак корів заводських ліній червоної степової породи дніпропетровського зонального типу в умовах взаємодії «генотипхсередовище» // Вісник Дніпропетровського державного 
аграрного університету. Дніпропетровськ, 2006. № 1. С. 126-129.

4. Мацеевский Я., Земба Ю. Генетика и методы разведения животных : пер. с пол. М. : Высшая школа, 1988. 447 с.

5. Мовчан Т. В., Данько В. І. Селекційно-генетичні параметри молочної продуктивності корів новостворюваної червоної молочної породи // Розведення і генетика тварин: міжвід. тематич. наук. зб. К. : Аграрна наука, 2005. Вип. 39. С. 140-145.

6. Панасюк І. М. Продуктивність і відтворні якості голштинських корів канадської селекції в умовах степової зони України // Науковий вісник Львівської державної академії ветеринарної медицини ім. С. 3. Гжицького. Львів, 1999. Вип. 3. Ч. 1. С. 224225.

7. Селекція молочної худоби і свиней : навч. посібник / Т. В. Підпала, С. А. Войналович, В. Г. Назаренко, В. В. Герасименко, Л. О. Стріха, О. К. Цхвітава ; за ред. професора Т. В. Підпалої. Миколаїв : МНАУ, 2012. 297 с.

8. Analysis of longevity traits and productivity of crossbred dairy cows in the Tropical Highlands of Ethiopia / K. Effa [et al.] // J. of Cell and Animal Biology. 2013. Vol. 7. No. 11. P. 138-143.

9. Association between somatic cell count during the first lactation and the cumulative milk yield of cows in Irish dairy herds / S. C. Archer [et al.] // DairySci. 2014. Vol. 97. No. 4. P. 2135-2144.

10. Comparison between sire-maternal grandsire and animal for genetic evaluation of longevity in a dairy cattle population with small herds / J. Jenko, G. Gorjanc, M. Kovac et al. // Dairy Sci. 2013. Vol. 96. No. 12. P. 8002-8013.

11. DuToit J., VanWyk J. B., Maiwashe A. Correlated response in longevity from direct selection for production in the South African Jersey breed // Animal Sci. 2012. Vol. 42. No. 1. P. 38-46.

12. Miglior F., Muir B. L., Van Doormaal B. G. Selection indices in Holstein cattle of various countries // Dairy Sci. 2005. Vol. 89. P. $1255-1263$.

13. Козир В. С., Коваленко В. П., Геккієв А. Д. Продуктивність голштинів різної еколого-генетичної генерації і української чорно-рябої молочної породи в умовах степової зони України // Розведення і генетика тварин : міжвідомч. темат. наук. зб. Київ : ФОП Рибаченко О.М., 2017. Вип. 53. С. 131-139.

14. Ференц Л. В., Полуліх М. І., Ільницька Г. В. Вплив живої маси телиць української чорно-рябої молочної породи у різні вікові періоди на їхню подальшу молочну продуктивність // Науковий вісник Львівського національного університету ветеринарної медицини та біотехнологій ім. С. 3. Ґжицького. Львів, 2018. Т. 20. № 84. С. 104-108. doi: 10.15421/nvlvet8420.

15. Адаптаційна здатність корів різного генетико-екологічного походження / Л. М. Хмельничий, В. В. Вечорка, В. М. Бондарчук, Є. А. Самохіна // Вісник Сумського національного аграрного університету : науково-методичний журнал : серія «Тваринництво». Суми, 2016. Вип. 7(30). С. 121-125.

16. Хмельничий Л. М., Вечорка В. В. Сполучена мінливість промірів та індексів будови тіла з надоєм корів української чорно-рябої молочної породи // Розведення і генетика тварин : міжвідом. тематич. наук. зб. К. : ТОВ «Аквамарин-ексклюзив», 2015. Вип. 50. С. 96-102.

17. Цуп В. І., Ящук Т. С., Василів А. П. Селекційна ситуація у племінних господарствах з розведення великої рогатої худоби Тернопільської області та шляхи їі покращення // Розведення і генетика тварин : міжвідом. тематич. наук. зб. К. : ТОВ «Аквамарин-ексклюзив», 2015. Вип. 50. С. 112-117.

18. Ясевін С. Молочна ферма : управління інформацією // Тваринництво сьогодні. 2017. № 5. С. 24-25.

19. Пат. 15061 А Україна, МКВ А 01 К 67/00 Спосіб оцінки якості генотипу бугая / Полковникова О. П.; заявник і патентовласник Інститут тваринництва Української академії аграрних наук. № 9405074; заявл. 11.05.94 ; опубл. 30.06.97. Бюл. № 3. 5 с.

\section{Referenses:}

1. Kramarenko, S. S., Lugovyj, S. I., Ly'xach, A. V. and Kramarenko O. S., 2019. Analiz biometrychnykh danykh u rozvedenni ta selektsii tvaryn [Analysis of biometric data in breeding and selection of animals]. Mykolaiv.

2. Bashchenko, M. I. and Khmelnychyi, L. M., 2002. Adaptatsiini osoblyvosti holshtyniv nimetskoi selektsii [Adaptive features of Holsteins of German selection]. In: mizhvid. tematych. nauk. zb. : «Nove v selektsii, henetytsi ta biotekhnolohii tvaryn». Rozvedennia i henetyka tvaryn, Materialy nauk.-vyrob. konferentsii. Kyiv, issue 36, pp. 28-29.

3. Gill, M. I., 2006. Komponenty fenotypovoi minlyvosti selektsiinykh oznak koriv zavodskykh linii chervonoi stepovoi porody dnipropetrovskoho zonalnoho typu v umovakh vzaiemodii «henotypxseredovyshche» [Components of phenotypic variability of selection traits of cows of factory lines of red steppe breed of Dnipropetrovsk zonal type in the conditions of interaction "genotype $\times$ environment"]. Visnyk Dnipropetrovskoho derzhavnoho ahrarnoho universytetu, no. 1, pp. 126-129.

4. Maceevskij, Ja. and Zemba, Ju.,1988. Genetika i metody razvedenija zhivotnyh [Genetics and methods of animal breeding]. Moskva.

5. Movchan, T. V. and Danko, V. I. 2005. Selektsiino-henetychni parametry molochnoi produktyvnosti koriv novostvoriuvanoi chervonoi molochnoi porody [Selection-genetic parameters of milk productivity of cows of newly formed red dairy breed]. Rozvedennia i henetyka tvaryn, issue 39, pp. 140-145.

6. Panasiuk, I. M., 1999. Produktyvnist i vidtvorni yakosti holshtynskykh koriv kanadskoi selektsii v umovakh stepovoi zony Ukrainy [Productivity and reproductive qualities of Holstein cows of Canadian selection in the steppe zone of Ukraine]. Naukovyi visnyk Lvivskoi derzhavnoi akademii veterynarnoi medytsyny im. S. Z. Hzhytskoho, issue 3, pp. 224-225.

7. Pidpala, T. V., Vojnalovych, S. A., Nazarenko, V. G., Gerasymenko, V. V., Strixa, L. O. and Czxvitava, O. K., 2012. Selekciya molochnoyi xudoby i svynej [Breeding of dairy cattle and pigs]. Mykolaiv.

8. Effa K., 2013. Analysis of longevity traits and productivity of crossbred dairy cows in the Tropical Highlands of Ethiopia. J. of Cell and Animal Biology, Vol. 7, no. 11, pp. 138-143.

9. Archer, S. C., 2014. Association between somatic cell count during the first lactation and the cumulative milk yield of cows 
in Irish dairy herds. DairySci, issue 9, no. 4, pp. 2135-2144.

10. Jenko, J., Gorjanc, G. and Kovac M., 2013. Comparison between sire-maternal grandsire and animal for genetic evaluation of longevity in a dairy cattle population with small herds. Dairy Sci., issue 96, no. 12, pp. 8002-8013.

11. DuToit, J., VanWyk, J. B. and Maiwashe, A., 2012. Correlated response in longevity from direct selection for production in the South African Jersey breed. Animal Sci., issue 42, no. 1, pp. 38-46.

12. Miglior, F., Muir, B. L. and Van Doormaal, B. G., 2005. Selection indices in Holstein cattle of various countries. Dairy Sci., issue 89 , pp. 1255-1263.

13. Kozyr, V. S., Kovalenko, V. P. and Hekkiiev, A. D. 2017. Produktyvnist holshtyniv riznoi ekoloho-henetychnoi heneratsii i ukrainskoi chorno-riaboi molochnoi porody v umovakh stepovoi zony Ukrainy [Productivity of Holsteins of different ecological and genetic generation and Ukrainian black-and-white dairy breed in the steppe zone of Ukraine]. Rozvedennia $i$ henetyka tvaryn, issue 53, pp. 131-139.

14. Ferents, L. V., Polulikh, M. I. and Inytska H. V., 2018. Vplyv zhyvoi masy telyts ukrainskoi chorno-riaboi molochnoi porody u rizni vikovi periody na yikhniu podalshu molochnu produktyvnist [Influence of live weight of heifers of Ukrainian black-spotted dairy breed in different age periods on their further milk productivity]. Naukovyi visnyk Lvivskoi derzhavnoi akademii veterynarnoi medytsyny im. S. Z. Hzhytskoho, issue 20, no. 84, pp. 104-108. doi: 10.15421/nvlvet8420.

15. Khmelnychyi, L. M., Vechorka, V. V., Bondarchuk, V. M., Samokhina, Ye. A., 2016. Adaptatsiina zdatnist koriv riznoho henetyko-ekolohichnoho pokhodzhennia [Adaptation ability of cows of different genetic and ecological origin]. Visnyk Sumskoho natsionalnoho ahrarnoho universytetu, issue 7(30). pp. 121-125.

16. Khmelnychyi, L. M., Vechorka, V. V., 2015. Spoluchena minlyvist promiriv ta indeksiv budovy tila z nadoiem koriv ukrainskoi chorno-riaboi molochnoi porody [Combined variability of measurements and body structure indices with milking of cows of Ukrainian black-spotted dairy breed]. Rozvedennia i henetyka tvaryn, issue 50, pp. 96-102.

17. Tsup, V. I., Yashchuk, T. S. and Vasyliv, A. P., 2015. Selektsiina sytuatsiia u pleminnykh hospodarstvakh z rozvedennia velykoi rohatoi khudoby Ternopilskoi oblasti ta shliakhy yii pokrashchennia [Selection situation in breeding farms of Ternopil region and ways to improve it]. Rozvedennia i henetyka tvaryn, issue 50, pp. 112-117.

18. Yasevin, S., 2017. Molochna ferma : upravlinnia informatsiieiu [Dairy farm: information management]. Tvarynnytstvo sohodni, no. 5, pp. 24-25.

19. Polkovnykova, O. P., 1997. Pat. 15061 A Ukraina, MKV A 01 K 67/00 Sposib otsinky yakosti henotypu buhaia. Instytut tvarynnytstva Ukrainskoi akademii ahrarnykh nauk. № 9405074; zaiavl. 11.05.94; opubl. 30.06.97. Biul. № 3. 5 p.

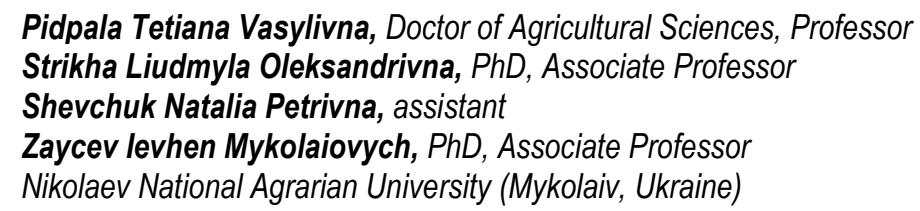

\section{Features of regression dependence of signs in cows of holstein breed of different selection}

It has been used general zootechnical methods (individual accounting of milk productivity, reproductive capacity), laboratory (determination of the quality of milk), variation-statistical method (regression analysis) during the research process. The material of the study was the data of milk productivity and reproductive capacity of cows of two generations of German Holstein breed ( $n=362$ ) and Ukrainian $(n=350)$ selection. The comparative analysis showed that the cows of the Holstein breed of German selection were characterized by lower regression coefficients of traits of milk productivity, except for the protein content in milk, than the animals of the Holstein breed of Ukrainian selection. At the same time, we observe a negative regression dependence on the fat content in milk (bD/M $=-0.182)$, which can be explained by the changes that occur in the process of adaptation of imported cattle to new technological conditions of operation. The cows of Holstein breed of Ukrainian selection set straight regression dependence of milk signs production, yield during 305 days of lactation $\left(b_{D / M}=0.274\right)$, the amount of milk fat $\left(b_{D / M}=0.279\right)$ and the number of milk protein $\left(b_{D / M}=\right.$ $0.258)$, the amount of milk fat per lactation $\left(b_{D / M}=0.227\right)$ and per day $\left(b_{D / M}=0.295\right)$. It is established that cows of Holstein breed of German selection, despite existence in different natural-climatic and forage conditions, keep not only a high level of productive signs, but also reproductive ability. According to the results of regression analysis, the presence of a rectilinear dependance between both breeding signs and individual traits in related groups of animals (daughter-mother) has established. This, in turn, allowed clarifying the effectiveness of selection in the formation of a highly productive herd of Holstein breed, which occurs through the introduction of uterine livestock and the use of bulls-breeders. A comparative analysis of the regression coefficients of productive signs of Holstein cows of Ukrainian selection revealed that more attention is paid to increasing milk yield in animals and due to this there is an increase in milk fat and protein in daughters which came from mothers of different productivity levels. According to the results of regression analysis, it was found that the selection of Holstein dairy cattle in increasing protein milk yield should be continued, as selection for fat milk production will be much less conducive to increasing the protein content in milk.

Key words: Holstein breed, productive signs, milk yield, regression.

Дата надходження до редакції: 10.03.2021 р. 